\title{
Evolving Poetic Maturity in the Poetry of Shiv K.Kumar
}

\author{
Goutam Karmakar ${ }^{1}$ \\ Assistant Teacher, Department of English, Bhagilata High School (H.S), \\ Raiganj, Uttar dinajpur, West Bengal, India
}

\begin{abstract}
Among the new poets, Shiv K.kumar is considered as one of the major poets of Indian English Poetry. His poetry gives a new sense of direction and identity to Indian English Poetry. Like a true modern poet, his poetry also deals with pain, suffering, hopes, agonies, contemporary reality, love, sex, national identity and many other elements. His subject matter is very simple and he treats every natural object in a vivid way. A kind of liveliness in expression is found in his poetry. Like other Indian English poets, his poetry also shows Indianness in both in his themes and contents. Close looks to his poems show that there is a gradual poetic development and maturity found in his poetry. His poetic consciousness is evolving and his maturity as a poet both in thought and perception is clearly visible. This paper attempts to highlight Kumar's growing consciousness and maturity coupled with reason, thought, irony and wisdom throughout his volumes.
\end{abstract}

Keywords: Love, Death, Landscape, Irony, Reason, Wisdom.

\section{INTRODUCTION}

Shiv K.Kumar is one of the leading poets of Indian English literature and the source of inspiration for the poets of younger generation. But what the poet he is now not was the case in the beginning point. He was a late bloomer and his devastating experience of divorce seta the tone for the creative writing of the poet. After the divorce, he took four years to recovery and he came back with new themes. His poetry then provides a new identity; seek for something and his perception chances in the following years. What sets him as a major postmodern as well as postcolonial poet of Indian English poetry are his eight volumes of poetry namely Articulate Silences (1970), Cobwebs in the Sun (1974), Subterfuges (1976), Woodpeckers (1979), Trapfalls in the Sky (1986), Woolgathering (1998), Thus Spake the Buddha (2001) and Loosing My Way (2001). What Iyengar says about the beginning volumes of his poetry is really true, "his sense of form and feeling for precise evocative language, as also his restless cerebration and his edged sensibility." (Iyengar, 722)

Throughout his poetic career, he selects many themes and issues for his poetry and appears before the reader as an individuating poet. The surrounding, Indian landscape, realities, his own way of thinking with reason, his theological outlook and philosophical bent of mind flash in his volumes and his maturity as a poet is also shown. He is very much outspoken and declarative about his thoughts and experiences. What he likes comes in his poems and his thoughts, themes and subject matter of the poems also reflect that liking. In order to relate with the phenomena around him, he moulds his experiences and expresses them in his own way. Everything is presented in a different way. He does not want to escape and run away from this world like Keats. But rather he faces them boldly as his conscious mind is fully under his control and it seems that he reaches the level of maturity, growth and sublimation with perfection.

Kumar's verse shows the reader the hidden vistas in man's inner life and like dreams man can conjure up imagination in course of reading his poems. He is not in a very complaining mood when he describes his surrounding and atmosphere. Rather he is cool, calm and serene. Actually "He becomes...a realist...a writer not turning away from pain and ugliness of life." (Mukherjee, 232). His poems clearly show his agility and alertness regarding experience and life. Simple themes like love, sex are also treated in a different way. Actually his poetry "is always an expression of the innate feeling of his protagonist in the subjective mode." (Singh, 92). In his poems like 'Cerebral Love', 'A Letter from New York' and 'Dark Mood', his treatment of love and sex show his evolving poetic maturity.

In his 'Cerebral Love', one can see the poet lost in a position of speculation in pursuit of metaphysical love. Here the central idea of the poem is sex which enables one to transcend the existential limitations. The poem is all about possibility and speculation. A sense of urgency to get some relief is found here and it is occurred due the failure in

${ }^{1}$ Corresponding Author: goutamkrmkr@gmail.com 
the act of sex. Here the poet is found leaving his female partner's body without doing any physical relationship. Love-making holds no importance to him. He seems to rise above bodily pleasure and his maturity in love making also can be seen. Here the poet says:

"Even in bed

myself copulates with its own dry bones

leaving her body

pensile on the tide's crest." (Cerebral Love)

Kumar's thinking about sex and love is not like the others. His 'The Dark Mood' projects man's love for a woman and this love is full of loyalty. He is here in a feministic mood and asks the man to show love and care for his woman. He also says that man must make physical relation with his woman and perversion should hinder this. Here the poet says:

"A man should come to his woman whole

not when the mind

is a perverted sunflower

turning face to darkness." (The Dark Mood)

Kumar's attitude to sex is more clearly reflected in his 'A Letter from New Work'. His self control is shown here. Here he is shown as a man of strong will and his soul is in full control. The poet projects the poet's journey to an alien land and during this journey he discovers his own self. In this land his friends indulge in sexual relation but the poet successfully avoids all these and that he is maturing as a human being both in body and mind is shown here. The poet says here:

"But my soul is still my own

The other evening they came-

Allen and Linda, Dick and Grace, Jack and Su

dripping bourbon from their lips.

They mated in my kitchen

behind the book-racks,

even brought me a blind date.

But something held back my hand

was it damyata?

or my mother's last wish,

or a diffidence nourished

on black coffee and white bread?" (A Letter from New Work)

His growing maturity is also visible in the dichotomy between reason and intuition. Reason for him works like a medium to cross check everything and intuition is the ability to percept something with the use of one's feeling. He uses both his reason and intuition to gain the ultimate knowledge and truth. Sometimes he depends solely on his intuition of his inner self to understand the mystery and meaning of life in a right way. Satish Kumar aptly says on this, "There is one reality at least which we all seize from within by intuition and not by simple analysis." (Kumar, 216). In his 'Indian Women' he shows the innocent women of India who wait peacefully for their husband till evening and they do it often leaving their household chores. But Western women consider waiting as the waste of time. Here the poet shows the conflict between reason of western women and intuition of Indian women who think that husband and housework are their first priority than any other work:

"Patiently they sit

like empty pitchers.” (Indian Women) 
But Kumar also gives importance to the reason. He says that the younger generation has no time to waste and they are going to be wise, selfish, critical to survive in this modern world while the older generation gives more value to intuition and not logical and rational like the younger generation. In his 'Letter to my Son', he shows the purest mind of a relationship and that is without logic and reason:

"Only last night, your mother

as she lay

beside me, mumbled in her dream

Oh, your troubled face

Sure, your diaper needs changing." (Letter to my Son)

As a poet of depth and maturity, he wants to attain peace and he says that it can be achieved intuitively. Reason and logic arte not needed to achieve it. In this world created by God for mankind peace is a very rare thing to get as it is replaced by greed, selfishness, terrors, quarrels and wars. Man is searching for peace. In his 'Buddha at Night Club', he shows exactly discussed above. Here in the poem a stranger searches peace even in a night club full of dancers, song and pomp. He is unable to find pleasure and takes pain by seeing others seeking fun through sex dolls. For the stranger all these are:

"Weaving endless cycles of

desire and pain, satiety

and ennui." (Buddha at Night Club)

But later the stranger starts to smile like Lord Buddha who receives enlightenment and also enriched with divine peace and wisdom in heart. So the poet says that to attain peace intuitiveness is needed and self recovery and discovery is possible at that stage. In his 'Border Guards', he conveys the message of peace by showing the relation between the sentinels of the enemy camp in the line of control during Indo-Pak war. He shows that the border guards develop a sweet relationship between them and by hearing one's tale of grief the other tries to console him without any hesitation. They feel the pain of each other and while consoling they can't touch to anyone as they belongs to rival nation. Intuition here dominates and reason also penetrates as the poet says:

"My fingers bleed to think

of the fence's spikes

that will not let me cares

the anguised face." (Border Guards)

The dichotomy between East and West is again found in his 'A Letter from New York'. The West is marked by disintegrated families and divorces. Love, compassion and understanding are very rare among them. He also states the country in its interior design is conspicuous for barrenness and emptiness of love but very well planed and designed externally. Contrary to this, people in East are happier and do whatever they like as rules are here flexible. His poetic maturity is shown when he compares this Eat-West condition humorously regarding rules, laws and discipline. Here he says:

"I sometimes stop at Grand

Central to piss

Where else can one ease

one's nerves." (TTCIP 56)

The subtle changes and difference between reason and intuition are found in his 'Lear to Cordelia'. Here he beautifully presents the love of a woman for her father and lover. He further says that it is impossible to confine love to any empiric point, territories, limits and boundaries. And he shows this through the conversation between Cordelia and King Lear. When King Lear asked her daughter about her love for her father, she replied logically that half of her love for her father and half for her lover. After hearing this reply Lear explains the love rightly: 
"Come, my dearest, feign

some movement of the soul

beyond the empiric point." (Lear to Cordelia)

Kumar's evolving poetic maturity is seen when he sees love and sex in between the ties of intuition and reason. To show love to our near and dear ones is a very common thing and here intuition plays a great role because it shows one's sincerity and genuineness towards other while showing love. Reason can't be the barrier between love and even sex because too much reasoning makes the love and sex a thing of boredom and one can't get any pleasure from it then. In his 'Married too Long', he shows exactly this. For the couples in this poem marriage appears to be dull and boring because of the couples' rational way of thinking in every moment. There creates a wide communication gap between them as the couples say here:

"We wear each other

like soiled underwear

I see you hung

On every wall

Like an obituary." (Married Too Long)

Kumar's poetry shows the true picture of rural India and like a true poet he depicts the landscape of India in his own way. In this case he can be classified also as a postcolonial poet because he wants to show colonized people's country and does not want to confine to the colonizer. He wants to present his native land in order to show his nation's rich cultural heritage also. He is a great lover of the landscape of India and his evolving poetic maturity is shown in the way he describes some particular place with simplification of thought, perception with brilliant image. In his 'Dal Lake: Srinagar', he shows the morning and the surrounding of Dal lake in a beautiful graphical way:

"It's daybreak-the moment of embrace

between rose and briar, dream and reality

faith and negation

The symphony of birds, still drunk

on some dreams of luscious orchards." (Dal Lake: Srinagar)

In his poem 'Banaras: Winter Morning', he describes the religious city Banaras in a beautiful way. The city is shown as a place of religion and in a winter morning it captives the poet so much that he says:

"If I were to die

this is the moment

and this is the place." (Woolgathering)

Kumar is always inspired by the city and notable places of India. As a postcolonial poet he depicts all these in his poems. He leaves no stone unturned. In his poem 'The Taj', he feels pity for the ruined beauty of such a monument as this is the one of the place which places India among other nations in terms of architecture and monuments. He says here:

"Fissures in its return

now a renovator's nightmare,

how long can it withstand

the riverbed's lethal teeth?" (The Taj)

Cities and places are also mentioned in his poetry. He also shows the climate, people and background in his poems to clear his point of view. In his 'A Letter to My Son' he shows the Hyderabad city, its surrounding, climate and extremes with the touch of reality. He is really an amazing paint of word picture. He says here: 
"But here in Hyderbad, I have drawn the curtains

to dodge the sun's sanguine eye

glowering in its lethal anger." (A Letter to My Son)

The landscape of India and the unequivocal specialty of India are discussed in his poems in a vivid way. Nature is also presented in his poems and in India people considers the river as mother. And this is also shown in his poetry by his description of the river Ganga. In his 'Cleansing Ganga', he gives a very fine picturesque description of this river. Here the poet describes the river, its surrounding and at night its beauty in beautiful graphical way:

"The moon will recapture in the river's mirrors

the shop lineaments of her own face

flushed like a bridge's

as she walks into the nuptial chamber

holding a long candle

to be snuffed out

into the Bay's eternity." (Cleansing Ganga)

A close look to some of his poems also shows that he is not only the painter of the landscapes and nature, but also a shrewd observer and commenter of all those things. He is really a conscious artist and satires the follies and foibles that is around him. So irony is a obvious thing found in his poetry and his maturity as a pot is also shown during this observation. His 'Feeling a Tree' shows his awareness towards environment and his commentary in this poem proves his intelligence and growing consciousness and all these are the results of awareness and conflicting experience. His maturity as a poet comes before the reader when he says that the loss of man's dignity is not less that death and his struggle and failure are the consequences in this journey. He says here:

"How can wood stand up against steel,

water against oil,

statement against its counter?

Humiliation is lethal

when the victim has no weapons for defence,

when you have to carry your own cross

and you are your own pyre-

Fuel, flame and ashes." (Felling a Tree)

In his 'Cleansing Ganga', he says that the river plays a vital role in everyone's life specially Hindus. But the people are very careless and do not pay any importance to clean it. The river which purifies the pilgrims and other people from their sin is now itself gets polluted. It is called the sacred and holy river of India but now it is not as pre as before it was:

“the Ganges' water can work

miracles like Lourdes'

inspite of the cartloads of dead men's ashes

and bones and the pundit's shit-

daily offerings to the Mother River!” (Cleansing Ganga)

Kumar in his poem 'O Delhi!' presents Delhi and its surrounding and also compares its present condition with past condition. Delhi in the past attracts Kumar more and now it only gives him pain and disillusionment. Bruce King rightly says in this case that 'In Shiv K. Kumar's poetry historical monuments, a landscape and environment are often viewed with a savage irony as part of his own sexual desires, anger at incongruities." (King,120). The city is 
now polluted and corrupted and he even uses a feminine image to show the condition of street of Delhi. He wants to show the contaminated reality of Delhi and irony is clearly visible here which gives the reader the real picture of the society. So as a poet his poetry even confirms the norms of postmodernism even. Here he says:

"Your streets and alleyways were like the contours

of a virgin's torso-taut and scented." (O Delhi!)

Some of the abstract and naked truth of the world carries special charm in Kumar's poetry. One such reality is death. In his 'Self-obituary', he shows the experience of death with lot of imageries. In this poem he accepts death in a calm quite way. He says that with a person's death the influences of the zodiac signs and stars go to another world with that dead person. All his struggles, discords and conflicts end with his death. In this poem his maturity as a poet is shown as he does not panic or undergoes tension while contemplating death. He says:

"If they'd not roasted him on the pyre,

one would have seen on his palms

all the zodiac signs of heaven and hell." (Self-obituary)

Death can be seen anywhere in any form. Even in love one can see death as death is there comes to show the ending of a relationship. In his 'Married Too Long', he shows death but not of any living or human being. Here love is gone between the couple and it is meant as death. Through the objective description the poet says this in this poem nd this gain shows his maturity as a poet. Actually death is the only reality and it can't be ignored or over-turned. Here the lover says:

"I see you hung

on every wall

like an obituary." (Married Too Long)

Kumar not only deals with love, death and contemporary surroundings in his poems. He is not a pessimistic poet at all and rather he knows how to face pain, sufferings and hard realities of life. Hope is still there and the virtue of man can't be destroyed easily by simple things. In his 'The Ring', he says: How could virtue be sullied/ by a night's affair?" (The Ring). His maturity is well observed in his 'Reclamation (for keith f.mckean)'. He says that hope is always latent in the new seed that is sown and about to sprout in due time and for this land must be properly ploughed and cultivated. Mingle of conscious and unconscious is seen here in these lines:

"Deep in the earth's bowels

there are seeds

that may have lain

untouched by moisture

awaiting reclamation." (CS 35)

Kumar's maturity and evolving poetic consciousness is seen some poems where he behaves like a sage or a wise man. In these poems he turns philosophical and turns from personal to impersonal and objective observation. In some poems he sees death from a philosophical point of view. In his 'A Dead Bird on an Electric Pole', his concept about death changes and he says death as an unbiased truth because it comes to all kinds of people and animals. All the human being and animals where good or bad, innocent or ignorant face death when the time comes and death simply puts an end to their lives through his instrument like the electric chair in this poem. The poet says here:

"The electric chair is neutral

to bird, assain and saint." (A Dead Bird on an Electric Pole)

Kumar like a yogi and saint sometimes believes about the rebirth of life after death. Resurrection and reconciliation occur after the departure from the earth destroying the physical existence. He believes in life-in-death situation and also believes about the existence of some spirit. His 'Clouds' shows his maturity as a poet as he emerges as a divine 
spririt who rises himself from this mundane existence. Here in this poem he projects the cloud in a different way and his hope in this cloud labels him with some great optimistic like Robert Browning. He says here:

"But to fade away is not to die

for there's always resurrection." (Clouds)

He is gradually rising actually towards knowledge leaving behind his ignorance. Kumar's philosophical journey can be classified as a journey from innocence to experience. He realizes what truth is and he also comes to know that knowledge and the realization of ultimate truth finally leads to death. He understand the work of Aristotle more clearly particularly Anagnorisis. All these are shown in his 'Adam to Eve' where Adam asks Eve:

"And if to know is die

why not perish together?" (Adam to Eve)

Kumar realizes that past plays an important role in shaping present life because it is not possible to avoid past deliberately and the past gives a person lesson on how to behave in the present situation when time is not favorable. The past reminds one that evil or bad times can come any time even in time of peace, joy and serenity and the past also makes man aware about the incidents done with him before and can be done again. Here Kumar seems to be a prophet and this is shown in his 'Shadow Lines':

"You cannot dodge the past all the time;

it resurges more sinisterly

during moments of complacency

reminding you

that you may see your doom

even in still waters." (Shadow Lines)

Kumar in his later poems wants to realize the value of life, the ultimate truth, knowledge which leads to wisdom and the moment of innocence. Myth, Indian epics and his reading of Indian theology attain him to the status of Nissim Ezekiel. His spiritual consciousness can be best summed up in his two poems namely 'Lord Krishna to Arjuna' and 'Renunciation'. These poems are imbued with wisdom, philosophical explanation and actual wish of human being in their sub consciousness life. These poems also shows that fate is irrevocable and one has to accept faith in spite of the fact that this acceptance of fate leads to pain, suffering and mental agony. In his 'Lord Krishna to Arjuna', he shows how Krishna dispels the ignorance of Arjuna and helps him realize his ultimate goal and truth of life. His reading of Bhagwat Gita helps him a lot to attain spiritual wisdom and Kumar like Arjuna attains a new status. Few lines from this poem show this:

"O Lord

can an act be divorced from the thought

of recompense?

That's man's ultimate frailty, O Warrior,

To know what lies beyond the horizon,

To know the end even before the beginning

Yor destiny was etched on your palm

At birth...A mentor too realizes himself

Through his disciple, like the creator

seeing his image in his creation." (Lord Krishna to Arjuna) 


\section{American Research Journal of English and Literature, Volume 1, Issue 3, June 2015 ISSN 2378-9026}

Kumar realizes that no one can change fate and has to accept one's lot with calm resistance. He also realizes that sufferings, hardship and pain are inseparable part of human life and one has to deal with it. No one can take this pain and every individual must have to know the way to deal with it. In his 'renunciation' he shows these and this poem echoes the previous poem discussed above. Here he says:

"Pain, he has now learnt, is born

in the mother's womb, and ends only

when the ashes are silenced-

by a sprinkling of milk.

This happened, more than two millennia ago

when sages lived in cages, in harmony

with the wind, rain, thunder-

and the beasts." (Renunciation)

\section{CONCLUSION}

So from the above discussion it is very much clear that Shiv K.Kumar emerges as a mature poet of Indian English poetry who does not defeated or destroyed or bends under any circumstances. He is really a poet of individuality and his thinking and perception is really unique him from others. A sustained development and a luxurious growth mark his poetry. He emerges before the reader as an articulate poet whose maturity, poetic growth and development make his poems popular and unique before his reader. His poetic career advances with his perception and conception which changes as one can see that. His thinking and imagination regarding love and sex mark this. Later his description of Indian landscape and his close scrutiny over this, his use of irony, his intuition and logical way of thinking and later his efforts to attain wisdom and knowledge prove that he emerges as a poet of maturity. These also help him to overcome his frustration and tension, conflict, contradiction and discord. Finally his assimilation with his self projects him not only as a poet of maturity but also a prophet.

\section{REFERENCES}

[1] Kumar, Shiv K. Cobwebs in the Sun. New Delhi: Tata McGraw-Hill, 1974. Print.

[2] Kumar, Shiv K. Subterfuges. New Delhi: Oxford University Press, 1976. Print.

[3] Kumar, Shiv K. Woodpeckers. London: Sidgwick \& Jackson, 1979. Print.

[4] Kumar, Shiv K. Woolgathering. Bangalore: Orient Longman, 1998. Print.

[5] Kumar, Shiv K. Journal of South Asian Literature. Vol. XXV-No.2, 1990. Print.

[6] Iyenger, K.R.Srinivasa. Indian Writing in English. New Delhi: Sterling, 1984. Print.

[7] Das, Bijay Kumar. Shiv K.Kumar as a Post-colonial Poet. New Delhi: Atlantic Publishers \& Distributors, 2001. Print.

[8] Kumar, Satish. A Survey of Indian English Poetry. Bareilly: Prakash Book Depot, 2001. Print.

[9] King, Bruce. Modern Indian Poetry in English. New Delhi: Oxford University Press, 1987. Print.

[10] Singh, Prabhat K. "The Poetry of Shiv K.Kumar.” A Passage to Shiv K.Kumar: From Agony to Ecstacy. New Delhi: Sarup \& Sons, 2001. Print.

[11] Mukherjee, Tutun. "Another Look at Modern Indian Poetry Written in English." Indian English Poetry: Critical Perspectives. Ed. Jaydipsinh K.dodiya. New Delhi: Sarup \& Sons, 2001. Print. 